\title{
A Quasi-Synoptic Survey of the Thermocline Circulation and Water Mass Distribution Within the Canary Basin
}

\author{
ROLF H. KäSE \\ Institut für Meereskunde, Universität Kiel, Federal Republic of Germany \\ James F. Price and Philip L. Richardson \\ Woods Hole Oceanographic Institution, Woods Hole, Massachusetts \\ WALTER ZenK \\ Institut für Meereskunde, Universität Kiel, Federal Republic of Germany
}

\begin{abstract}
Shipboard hydrographic measurements and moored current meters are used to infer both the largescale and mesoscale water mass distribution and features of the general circulation in the Canary Basin. We found a convoluted current system dominated by the time-dependent meandering of the eastward flowing Azores Current and the formation of mesoscale eddies. At middepths, several distinctly different water masses are identified: Subpolar Mode and Labrador Sea Water are centered in the northwest, Subantarctic Intermediate Water is centered in the southeast, and the saltier, warmer Mediterranean tongue lies between them. Mesoscale structures of these water masses suggest the presence of middepth meanders and detached eddies which may be caused by fluctuations of the Azores Current.
\end{abstract}

\section{INTRODUCTION}

In this paper we use hydrographic and current meter data to describe some features of the circulation and water mass distribution within the Canary Basin. Our aim is to show both the large-scale $(O(1000 \mathrm{~km}))$ and mesoscale $(O(100 \mathrm{~km}))$ distribution of properties within the thermocline.

Recent studies of the climatic data base [Olbers et al., 1985; Stramma, 1984] show that the basic feature of the steady circulation within the upper main thermocline (above $800 \mathrm{~m}$ ) is the eastward flowing Azores Current. This current appears to branch from the Gulf Stream in the splitting region near $40^{\circ} \mathrm{N}, 40^{\circ} \mathrm{W}$ [Mann, 1967; Krauss, 1986] and is the principal eastern extension of the subtropical gyre across the MidAtlantic Ridge. It transports about $10 \times 10^{6} \mathrm{~m}^{3} \mathrm{~s}^{-1}$ eastward across $35^{\circ} \mathrm{W}$ between $30^{\circ} \mathrm{N}$ and $40^{\circ} \mathrm{N}$. The Azores Current turns southward between $25^{\circ} \mathrm{W}$ and the coast of Africa and feeds into the southwestward flowing North Equatorial Current.

The steady circulation within the deep main thermocline $(800$ to $1500 \mathrm{~m})$ is much weaker by comparison and not as well defined [e.g., Olbers et al., 1985]. Saunders [1982] made a careful study of geostrophic and Sverdrup transport in the eastern North Atlantic and deduced a westward transport of about $2 \times 10^{6} \mathrm{~m}^{3} \mathrm{~s}^{-1}$, which was approximately coincident with the Mediterranean salt tongue. Meridional transports were found to be weaker still. In the central Canary Basin there may be a weaker southwesterly transport aligned more or less with the transport in the overlying thermocline.

The mesoscale eddy field in the Canary Basin appears also to be dominated by the Azores Current [Käse and Siedler, 1982]. This current undergoes large amplitude north-south meandering [Käse et al., 1985] with occasional eddy detach-

Copyright 1986 by the American Geophysical Union.

Paper number $6 \mathrm{C} 0238$.

$0148-0227 / 86 / 006 \mathrm{C}-0238 \$ 05.00$ ment and significant lateral eddy heat flux. Within the deep thermocline this meandering and eddy detachment may contribute to the formation of discrete mesoscale lenses of Mediterranean water from the salt tongue which lies along the northern edge of the Canary Basin.

\section{Measurements}

Our data were taken in 1984 during two cruises aboard R/V Oceanus and a cruise aboard FS Meteor [Meincke et al., 1985]. During the Oceanus cruise we dropped 172 deep $(1800$ m) T5 expendable bathythermographs (XBTs) and another 37 shallow $(750 \mathrm{~m})$ T7 XBTs (see Figure 1 for drop locations). Fourteen hydrographic bottle casts were also made during the Oceanus cruise. Twelve Nansen bottles were set at depths from the surface to $2000 \mathrm{~m}$, and water samples were drawn to determine dissolved oxygen by Winkler titration (thought to be accurate to within $0.1 \mathrm{~mL} \mathrm{~L}^{-1}$ ) and dissolved silica by colorimetry (thought to be accurate to within $3 \mu \mathrm{g}$ atm $\mathrm{L}^{-1}$ ). During the Meteor cruise there were an additional 99 shallow XBT drops and 51 conductivity, temperature, and depth (CTD) stations occupied in the study area (see Figure 1). Yearlong records from a single current meter mooring, KIEL276, set at the NEADS 1 site $\left(33^{\circ} \mathrm{N}, 22^{\circ} \mathrm{W}\right)$ are also presented. This mooring had Aanderaa instruments which measured velocity and temperature at depths of $330 \mathrm{~m}, 560 \mathrm{~m}, 1160 \mathrm{~m}, 1660 \mathrm{~m}$, $3050 \mathrm{~m}$, and near the bottom at $5040 \mathrm{~m}$. The complete hydrographic and current meter data set gives us an opportunity to describe both the large-scale hydrographic field within the Canary Basin (1000-km scales) as well as the mesoscale variability around the Azores frontal region (100-km scales).

\section{Spatial Distributions}

\subsection{Meridional Sections}

Our sampling included two nearly meridional sections through the central Canary Basin (Figures 2 and 3). The first section is made up from eight Oceanus hydrographic stations 


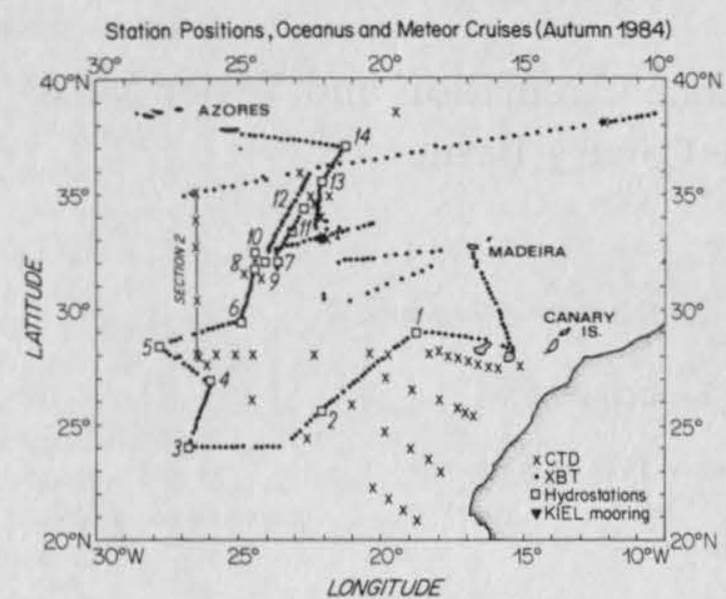

Fig. 1. Station positions occupied during October 1984 by $R / V$ Oceanus and by FS Meteor. The crosses denote CTD stations taken by Meteor, and the dots denote positions of XBTs launched from Meteor or Oceamus. Numbered squares denote hydrostations (which include oxygen and silica) made from Oceamus, and the triangle is the intermediate current meter mooring KIEL276 at the NEADS 1 location.

along approximately $25^{\circ} \mathrm{W}$. The second, shorter section (Figure 1) was made up from five Meteor CTD stations along $26^{\circ} 30^{\prime} \mathrm{W}$. The measurement accuracy for each of these is more than adequate for our purpose here; the precision of temperature and salinity of the hydrocasts is thought to be within 20 $\mathrm{mK}$ and 0.02 practical salinity units (PSU), respectively. CTD data were obtained by an instrument yielding precision of at least $10 \mathrm{mK} / 0.01$ PSU (T. Müller and N. Brown, personal communication, 1985).

Temperature distributions in Figure $2 a$ generally show two distinctive layers: the main thermocline or Central Water down to $600 \mathrm{~m}$, and the low-gradient region below. A characteristic feature above $200-\mathrm{m}$ depth is the thermostad in the $16^{\circ}-19^{\circ} \mathrm{C}$ range, which is often found in this region in connection with the Azores Current (stations 9-12). This is believed to be the remainder of local wintertime convection in the northern Canary Basin similar to the $18^{\circ}$ water of the Sargasso Sea [Worthington, 1976; Gould, 1985; Käse et al., 1985]. Except in the Azores Current region, isotherms in the Central Water are rather flat between stations 3 and 11. The most significant signal in the main thermocline is the divergence of the $9^{\circ}$ to $11^{\circ}$ isotherms at the northern end of the section caused by the warm Mediterranean Water (MW) north of $34^{\circ} \mathrm{N}$.

Both features, the $17^{\circ}-19^{\circ}$ thermostads and the warm MW expressions, are clearly reproduced in the salinity sections (Figure $2 b$ ). At $200 \mathrm{~m}$ one can distinguish a southern halostad around 36.80 and a northern one near 36.40 . Below $700 \mathrm{~m}$ a strong influence of $\mathrm{MW}$ becomes evident with salinities greater than 35.6 [Dietrich, 1969; Worthington, 1976]. The strongest MW salinity maximum is found at the northern end of the section at around $1100-\mathrm{m}$ depth, and there is a weaker maximum between $31^{\circ} \mathrm{N}$ and $33^{\circ} \mathrm{N}$. At the southern end of the section is low salinity due to the influence of the Subantarctic Intermediate Water (SAAIW). The steplike slope of the 35.4 isohaline represents a front which can be traced in silicate and oxygen throughout the upper ocean. This marks the transition between the northern spreading SAAIW and the southern edge of the MW tongue.

This transition zone is obvious also in the silica section
(Figure $2 c$ ) separating silica-rich SAAIW below $1400 \mathrm{~m}$ from silica-poor waters $\left(>16 \mu \mathrm{g}\right.$ atm $\left.\mathrm{L}^{-1}\right)$ of northern hemisphere origin. The separation zone continues upward following the main thermocline, as is evident from the steep slope of the 6 $\mu \mathrm{g}$ atm $\mathrm{L}^{-1}$ isoline. Owing to high biological productivity, the near-surface layer has silica values of only $1 \mu \mathrm{g}$ atm $\mathrm{L}^{-1}$ or less.

The $\mathrm{O}_{2}$ section (Figure $2 d$ ) is somewhat different from the other property distributions. The main features consist of two different $\mathrm{O}_{2}$ minima at the 800 - to $900-\mathrm{m} \mathrm{level,} \mathrm{one} \mathrm{in} \mathrm{the}$ south and one in the north. The dominant minimum oxygen values, below $3.4 \mathrm{~mL} \mathrm{~L}^{-1}$, are found on the southern side of the section. It extends as a low oxygen tongue northward up to $28^{\circ} \mathrm{N}$, where the general north-south transition zone in the main thermocline occurs in the MW range. The second minimum which has values below $4.2 \mathrm{~mL} \mathrm{~L}^{-1}$ is centered just above the MW tongue. The MW core apparently has no pronounced $\mathrm{O}_{2}$ signal. Below the MW lower boundary is an oxygen-rich layer of $>5.6 \mathrm{~mL} \mathrm{~L}^{-1}$ resulting from convectively formed water masses of subpolar origin.

A noticeable feature in the upper $500 \mathrm{~m}$ is the dip of the 4.6-5.0 $\mathrm{mL} \mathrm{L}^{-1}$ oxygen contours between stations 13 and 12 . This appears to be a signature of subduction or advection of colder, fresher, oxygen-rich water from the northern flank of the Azores Current. The opposite trend is found at depths greater than $1200 \mathrm{~m}$, where oxygenated deep water is advected and upwelled from below.

\subsection{Parameter Correlation}

For further clarification of water masses present in the upper layers of the Canary Basin, we display scatterplots of temperature, salinity, oxygen, and silica obtained from the hydrographic series (Figure 4).

Most of the variability in temperature versus salinity $(\mathrm{T} / \mathrm{S})$ is concentrated near the surface and in the MW. Surface salinity ranges between 36.5 and 37.3 ; the high values are due to the high evaporation rate in the subtropics. At middepths around $1000 \mathrm{~m}$ there is a highly variable MW range in which high salinity occurs in the north (station 14) and low salinity occurs in the SAAIW in the south (station 3). The transition zone between SAAIW- and MW-influenced regions is evident also in the $\mathrm{S} / \mathrm{O}_{2}$ and $\mathrm{Si} / \mathrm{O}_{2}$ diagrams (Figures $4 b$ and $4 c$ ) as two $\mathrm{O}_{2}$ extrema separated roughly by $0.9 \mathrm{~mL} \mathrm{~L}^{-1}$. The least scatter is found in the North Atlantic Central Water (NACW), which is representative of the main thermocline down to approximately $600 \mathrm{~m}$. Although $T / S$ curves are well correlated in the NACW, there is a meridional gradient in $\mathrm{O}_{2}$ due to a different ventilation age and oxygen utilization. In the deepest level, $T / S$ data from all stations converge.

\section{Large-Scale Horizontal Maps}

All available temperature data (see section 2) were compiled and plotted on a large-scale and a smaller-scale grid, the latter of which will be discussed in section 6 . Interpolation was done by nearest neighbor search, with smoothing weighted by the inverse distance. In the larger-scale map, the maximum search radius was $300 \mathrm{~km}$. Contouring was performed automatically. Temperature maps are shown at the three levels $(560,1160$, and $1660 \mathrm{~m}$ ) where we also have simultaneous long-term current and temperature records.

\subsection{Central Water Level: $560 \mathrm{~m}$}

The map from the main thermocline at $560 \mathrm{~m}$ contains the most data points of all three charts, since all T7-XBT $(750 \mathrm{~m})$ probes could be included (Figure $5 a$ ). A systematic linear pres- 

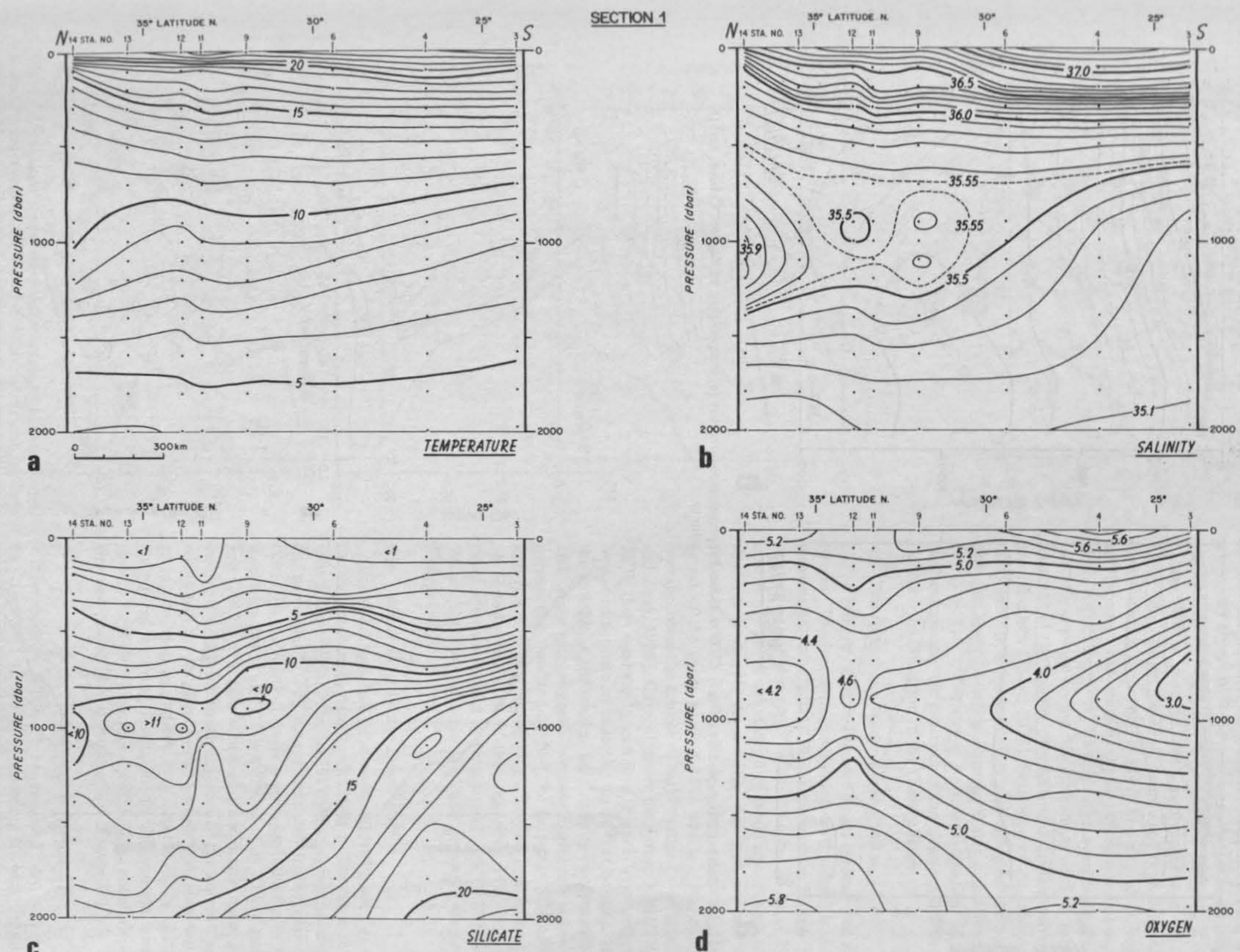

Fig. 2. Property cross sections (see Figure 1) occupied by Oceanus hydrographic stations. Station number is at top, and bottle depths are shown as dots. Properties measured are $(a)$ temperature in degrees Celsius; $(b)$ Salinity; $(c)$ Silica concentration, in $\mu \mathrm{g} \mathrm{atm} \mathrm{L}^{-1}$; and $(d)$ Oxygen concentration, in milliliters per liter. 


\section{SECTION 2}

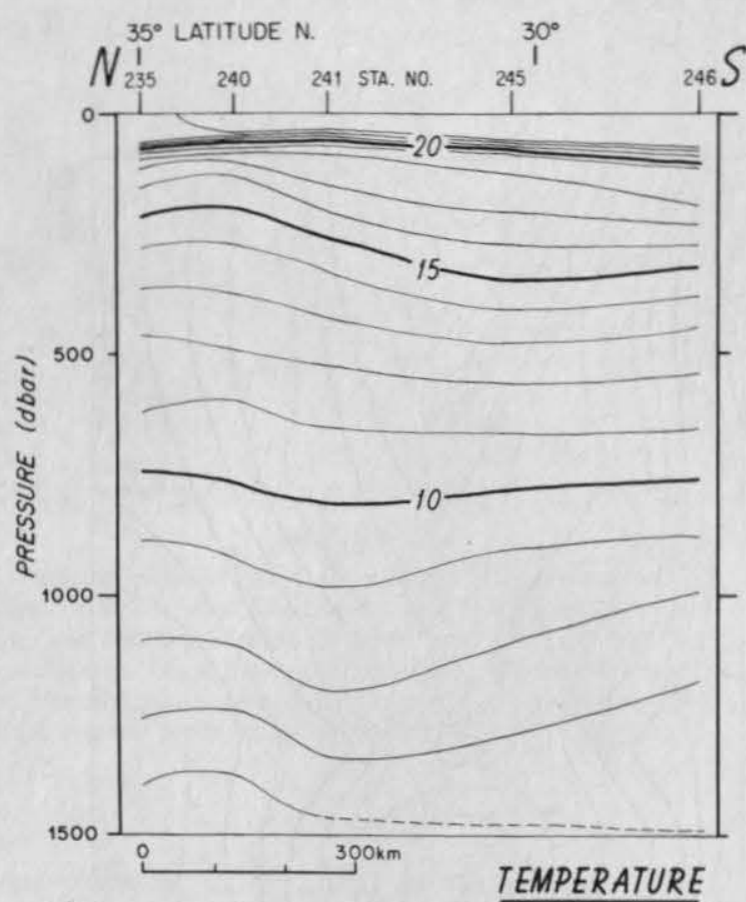

\section{a}

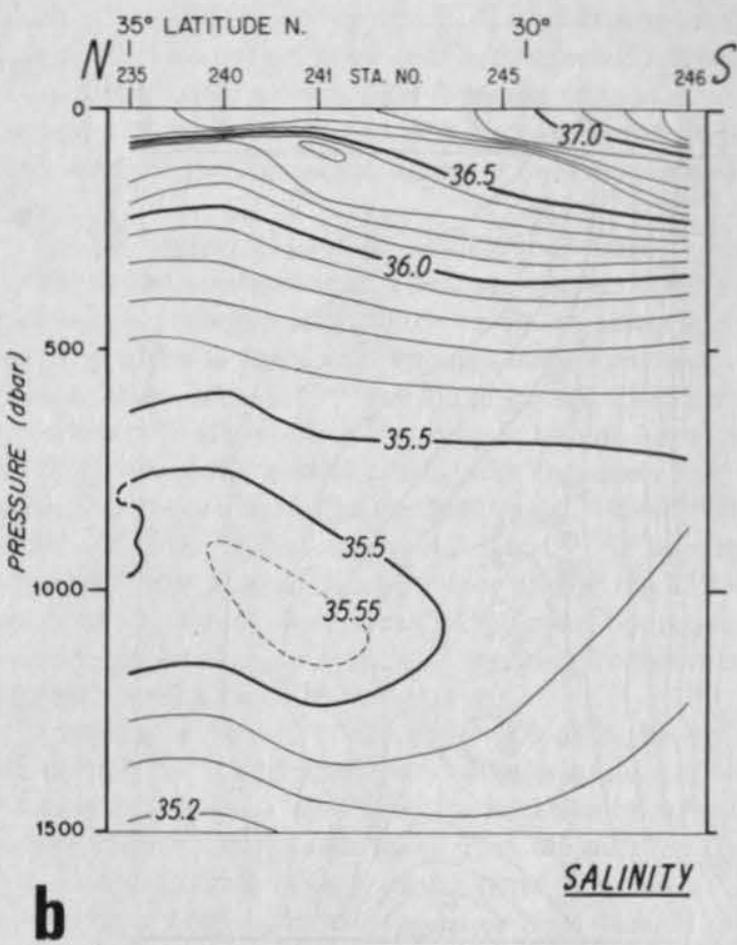

Fig. 3. Section 2 occupied by Meteor CTD stations. Properties measured are (a) temperature, in degrees Celsius, and (b) salinity.
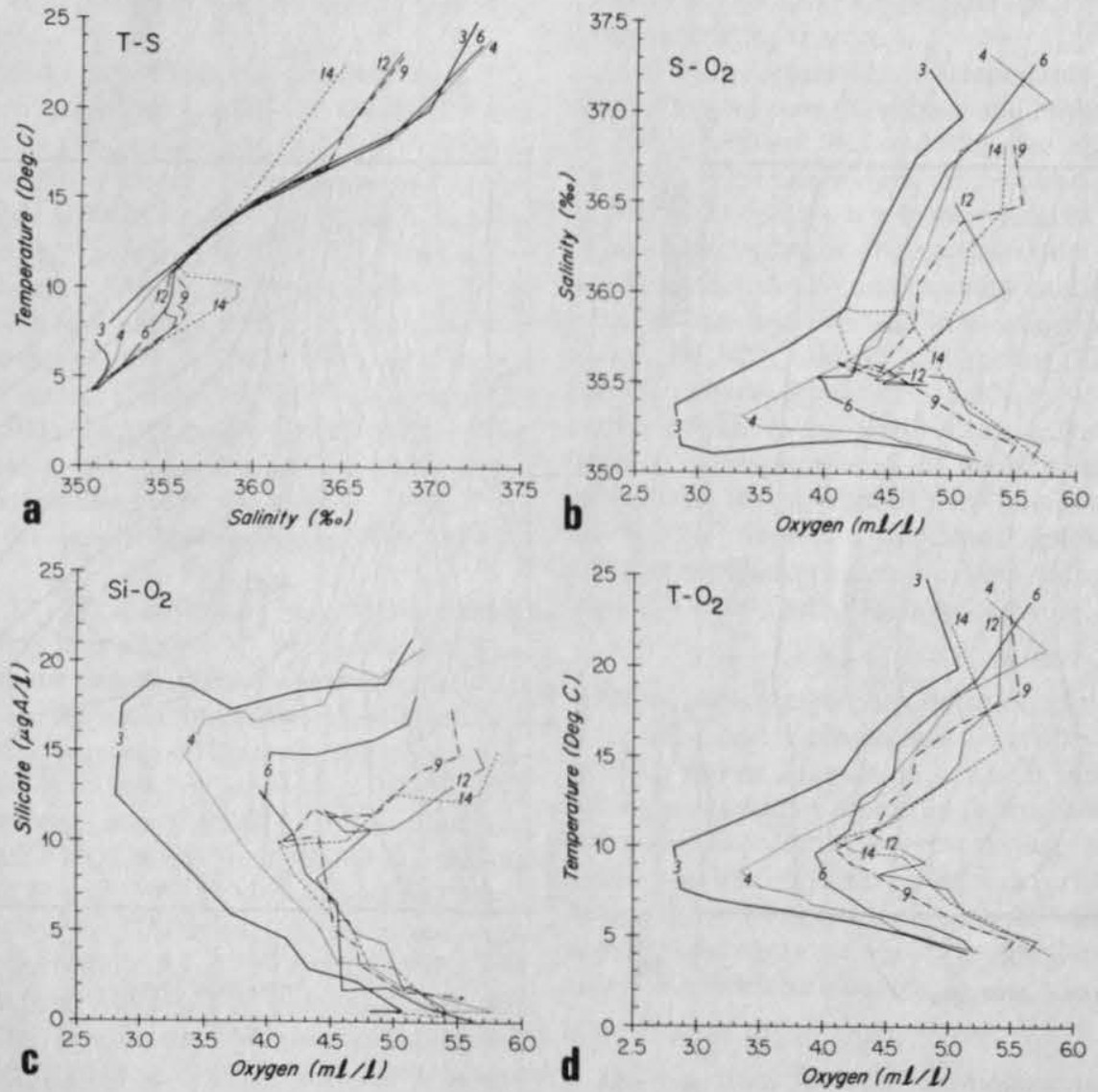

Fig. 4. Property diagrams from hydrographic stations along section 1. (a) Temperature versus salinity. (b) Salinity versus oxygen. (c) Silica versus oxygen. (d) Temperature versus oxygen. 

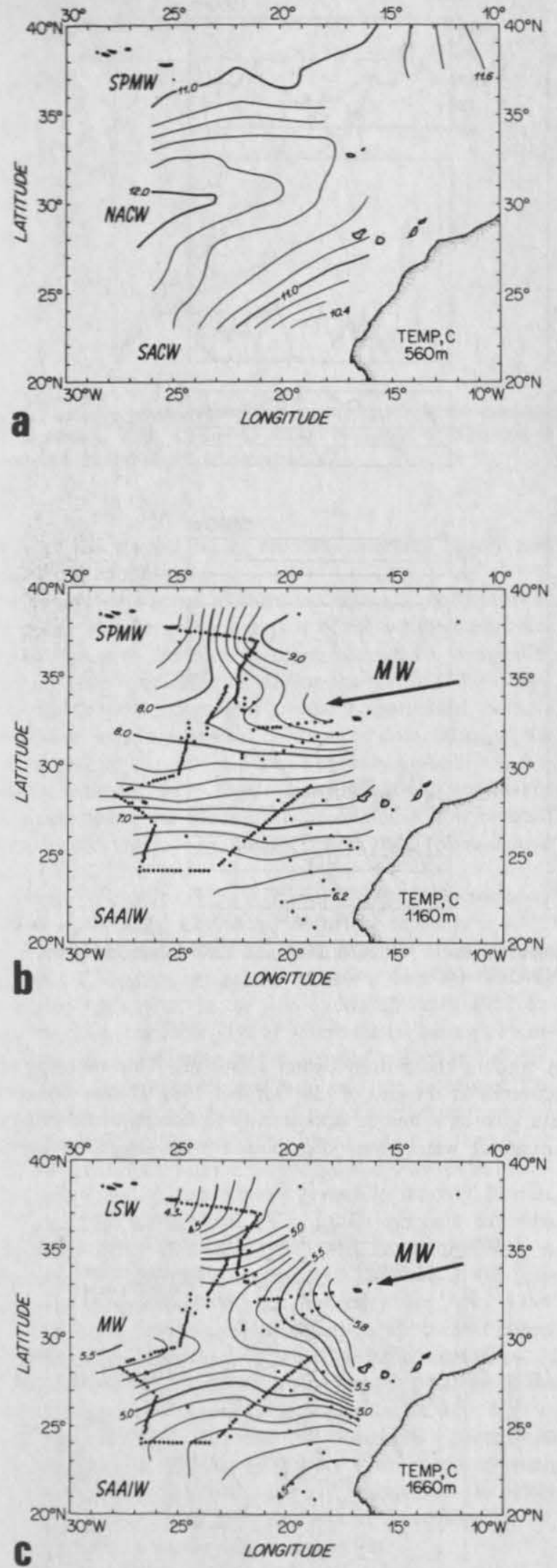

Fig. 5. Large-scale temperature distributions with water masses indicated by abbreviations (MW etc.) discussed in the text. (a) Temperature at $560-\mathrm{m}$ depth made using the full set of stations shown in Figure 1. (b) Temperature at 1160-m depth made from deep XBTs and the CTD and hydrographic station data at positions shown by dots. (c) Temperature at $1660-\mathrm{m}$ depth made from the data shown by dots. sure bias was removed from the XBT records by minimization of the difference between isotherm depths from hydrocast/CTD stations and XBT drops. The main feature is a circular distribution of isotherms around the warm $\left(>12^{\circ} \mathrm{C}\right)$ core at $29^{\circ} \mathrm{N}, 26^{\circ} \mathrm{W}$. This represents the inner subtropical anticyclonic gyre which recirculates east of Madeira. To its north is the Azores Current with temperatures of $11.2^{\circ}-11.6^{\circ} \mathrm{C}$ [Käse and Siedler, 1982]. A southward branching of this current, found by Stramma [1984] in historical data, could not be confirmed in our quasi-synoptic survey during autumn 1984. High temperature $\left(>11.6^{\circ} \mathrm{C}\right)$ in the northeastern corner apparently are due to the Mediterranean outflow following the coastline of the Iberian peninsula and the Gettysburg Bank at greater depth [Zenk, 1970]. Southeast of the subtropical gyre, the combined influences of the upwelling off the Sahara coast and the South Atlantic Central Water cause lower temperatures $\left(<11^{\circ} \mathrm{C}\right)$. The strong horizontal gradient of this region further indicates the presence of the Canary Current as part of the outer recirculation in the Canary Basin.

\subsection{Mediterranean Water Level: $1160 \mathrm{~m}$}

The 1160 -m chart in Figure $5 b$ cuts through the warm MW tongue. The isotherm distribution at this level is nearly independent of the Central Water pattern in Figure 5a. In the western part of the upper return flow, i.e., south of $29^{\circ} \mathrm{N}$, there is a nearly zonal orientation of isotherms. North of this latitude the isotherms resolved in this grid are normal to the Azores Current in Figure $5 a$. They represent the western extent of the warm pool of MW which in the climatological average forms the tongue of highly saline ( $>35.8)$ water [Käse and Zenk, 1986]. Current meter data from KIEL276 at $33^{\circ} \mathrm{N}$, $22^{\circ} \mathrm{W}$ show westward mean flow (Figure 7) coincident with the westward protrusion of isotherms at that latitude. This is also the location of the weaker MW salinity maximum (Figures $2 b$ and $3 b$ ), which suggests westward property advection in a narrow band around $32^{\circ} \mathrm{N}$. (The first-year SOFAR float trajectories from this region give a similar impression.) North of $36^{\circ} \mathrm{N}$ and west of $25^{\circ} \mathrm{W}$ the large-scale MW intrusion competes with southward advected cold $\left(<8^{\circ} \mathrm{C}\right)$ Subpolar Mode Water (SPMW) of higher-latitude regions [McCartney and Talley, 1982].

\subsection{Middle Deep Water Level: $1660 \mathrm{~m}$}

The third and last large-scale chart (Figure $5 c$ ) represents the temperature distribution at $1660 \mathrm{~m}$. The basic zonal orientation south of $29^{\circ} \mathrm{N}$ in the MW level is reproduced again in the deep, warm tongue now restricted to the vicinity of Madeira. To the north there is a stronger influence of the colder Labrador Sea Water (LSW), described by Talley and McCartney [1982]. The interaction of these water masses probably causes the high intermittency seen in the current meter data, which will be discussed in the next section. Here we only note an extended low-gradient area around $32^{\circ} \mathrm{N}, 23^{\circ} \mathrm{W}$ in the vicinity of mooring KIEL276. In the extreme southeastern corner there is evidence of cold SAAIW, noted already in the Oceamus salinity and silicate section (Figure $2 b$ ).

\section{MOORING Measurements}

The mooring KIEL276 as discussed here was deployed in October 1983. In the year preceding these hydrographic surveys, it recorded temperature and current velocity at three levels of the Central Water $(330 \mathrm{~m}, 560 \mathrm{~m}$, and $760 \mathrm{~m})$, the Mediterranean water level $(1160 \mathrm{~m})$, in the transition zone to the middle deep water $(1660 \mathrm{~m})$, in the lower deep water (3050 


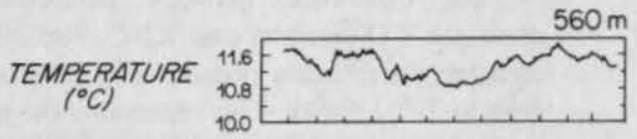

SPEED $(\mathrm{cm} / \mathrm{sec})$

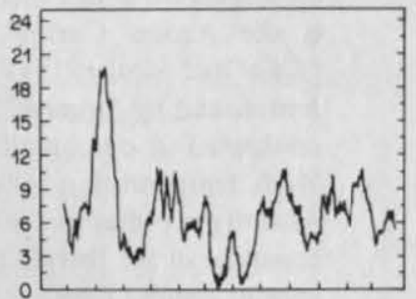

DIRECTION (०T)

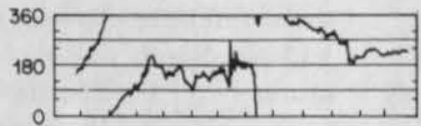

TEMPERATURE $\left({ }^{\circ} \mathrm{C}\right)$

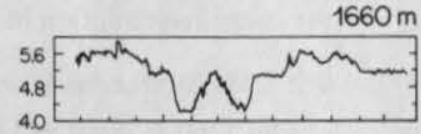

SPEED

$(\mathrm{cm} / \mathrm{sec})$

DIRECTION

(PT)

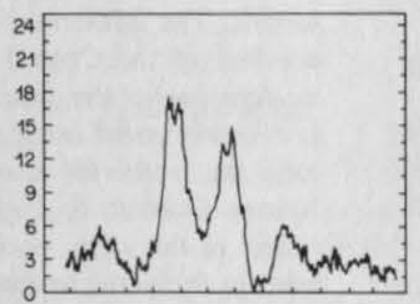

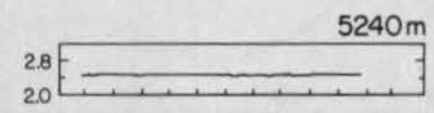
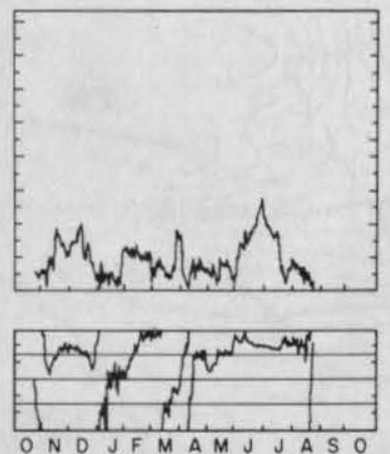

Fig. 6. Time series of temperature, current speed, and direction at depths of $560,1160,1660$, and $5240 \mathrm{~m}$ from mooring KIEL276 at the NEADS 1 site.
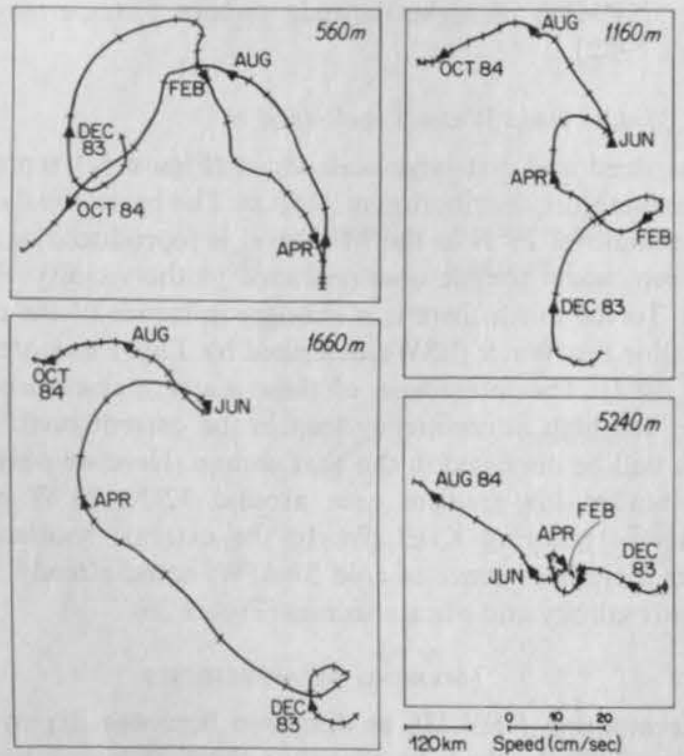

Fig. 7. Progressive vector diagrams. Tick marks are at 10-day intervals, and the first day of every other month is marked by a triangle pointing in the direction of the flow. The speed scale should be compared to a 10-day displacement. North is toward the top of the figure. $\mathrm{m})$, and in the bottom water $(5040 \mathrm{~m})$. This mooring was recovered at the end of the October 1984 Meteor cruise. Its data give us a unique opportunity to compare the observed horizontal water mass distribution with suggested particle

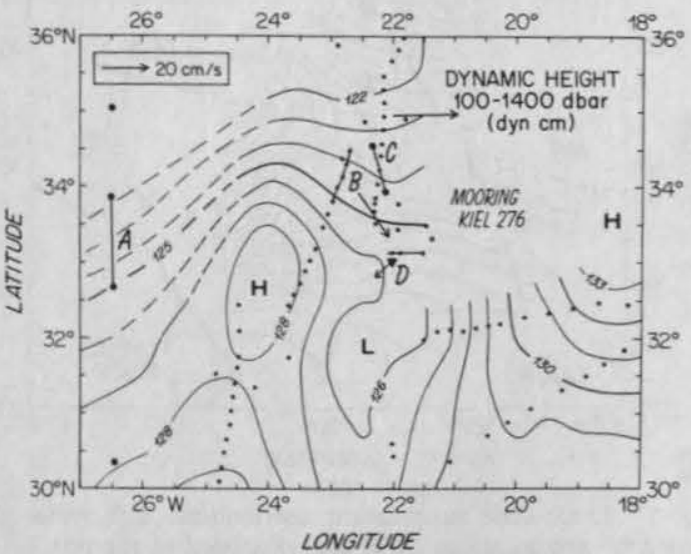

Fig. 8. Mesoscale distribution of dynamic topography (in dynamic centimeters) (dyn $\mathrm{cm})$ of 100 dbar relative to 1400 dbar. Station positions are denoted by dots. Ship drift observations and the velocity from the $560-\mathrm{m}$ current meter are shown as vectors (scale at upper left). 


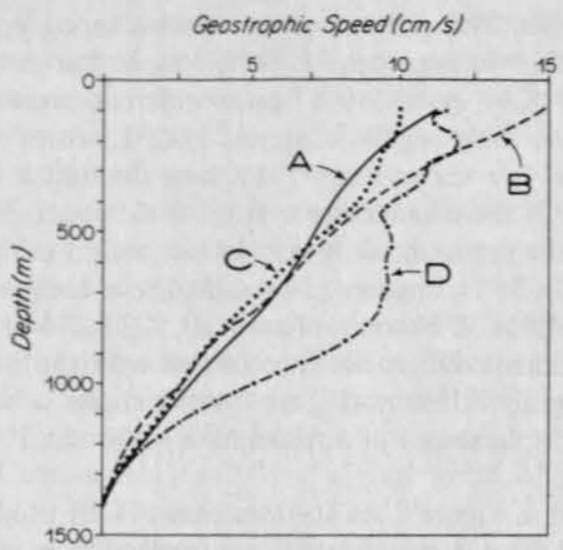

Fig. 9. Relative geostrophic velocity computed from the dynamic height at sections A, B, C, and D shown in Figure 8. Direction is eastward at A, B, and C, and southward at D.

paths from the current meter records, assuming steady and homogeneous conditions.

Low-passed time series of three instruments representative of the upper, middle, and lower part of the water column are shown in Figure 6. The corresponding progressive vector diagrams in Figure 7 indicate that during the period 1983-1984 a general north-south alignment of the hypothetical particle paths existed, with a westward component dominating at the end of the record (Figure 7b). From February to April a highly baroclinic structure seems to prevail; while flow is southward in the levels above the Mediterranean Water, a flow reversal occurs between the 760- (not shown here) and $1160-\mathrm{m}$ instruments.

In the first 3 months there is an anticyclonic loop superimposed on all records. Connected with this signal is a $0.4^{\circ} \mathrm{C}$ drop in temperature in the main thermocline central water and a rise of temperature in the midwater level of $>1.5^{\circ} \mathrm{C}$. This scenario is similar to the one in March-April 1982 described by Käse and Zenk [1986] where the switching of temperature between different basic states was related to the passage of highly saline lenses (meddies) past the moorings. The three possible states are best recognized in the temperature record from the 1660 -m-level. The "mean" state at that depth is $5.4^{\circ} \mathrm{C}$, which is found in the beginning and during the final 2 months as well as for some interim periods in January, March, and May. The warm state $\left(T>5.8^{\circ} \mathrm{C}\right)$ prevails for two periods, November-December 1983 and June-July 1984. A cold state $\left(T<4.6^{\circ} \mathrm{C}\right)$ is connected with the loop in the progressive vector diagrams between February and April 1984. This event is the most unusual signal in all current meter records since the beginning of the long-term monitoring in 1977. The velocity connected with this burst is maximal at the $1660-\mathrm{m}$ level and shows speed values larger than $15 \mathrm{~cm} \mathrm{~s}^{-1}$.

Note that the total westward displacement of more than $500 \mathrm{~km}$ is about the same at all depths. This leads to a mean westward advection speed of $2 \mathrm{~cm} \mathrm{~s}^{-1}$ throughout the water column. In terms of transport, this would correspond to $10^{7}$ $\mathrm{m}^{3} \mathrm{~s}^{-1}$ through a $100-\mathrm{km}$-wide cross section.

\section{Mesoscale Variability in the Central CANARY BASIN}

Earlier investigations in this region have revealed abundant mesoscale phenomena: the meandering Azores Current, patches of Subtropical Mode Water south of the Azores front,
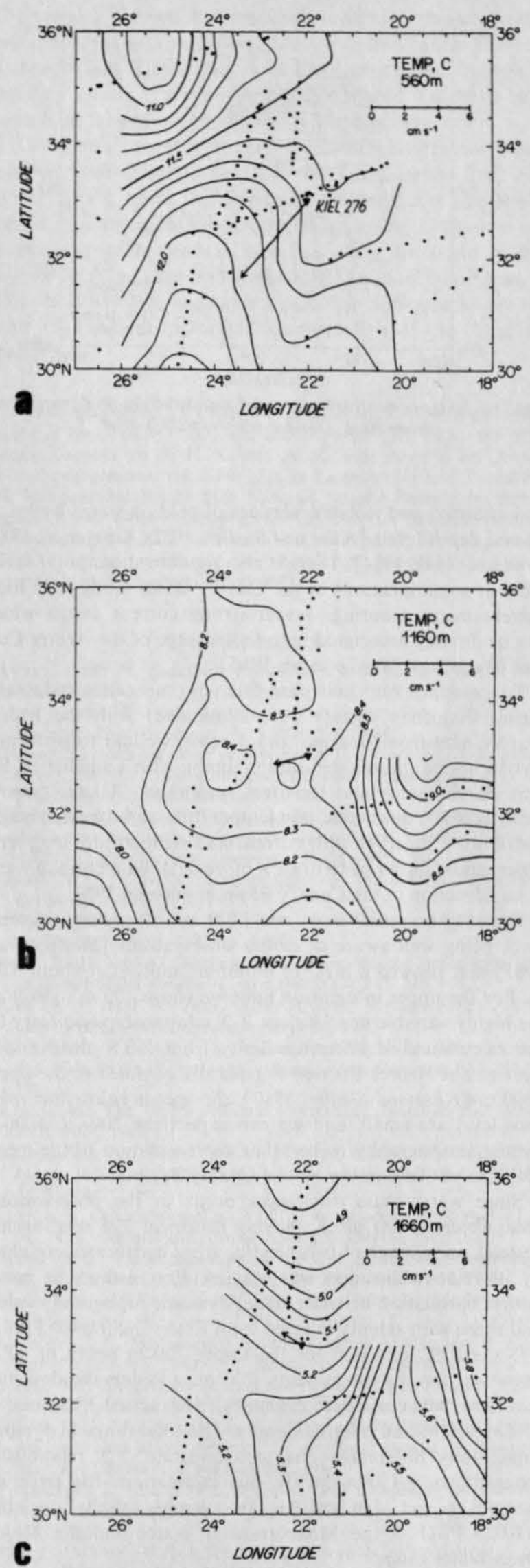

Fig. 10. Mesoscale distribution of temperature at (a) $560 \mathrm{~m}$ depth, (b) 1160-m depth, and (c) 1660-m depth. Station positions are shown as dots. 


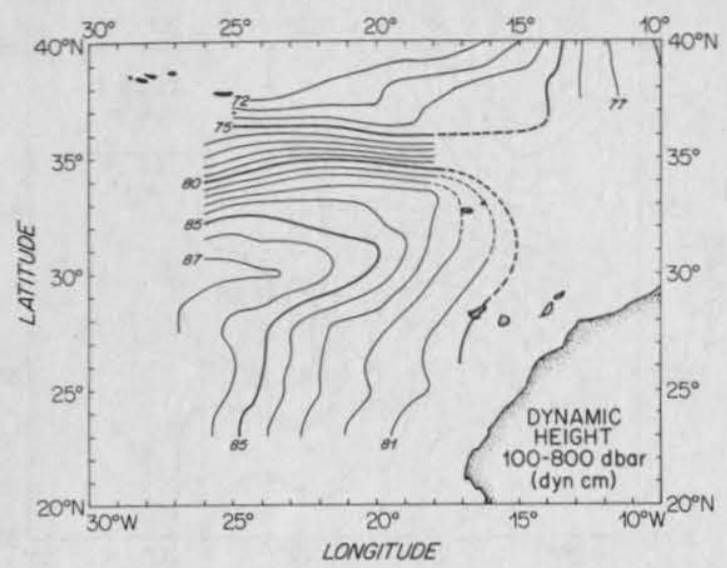

Fig. 11. Large-scale distribution of dynamic height (in dynamic centimeters) at 100 dbar relative to 800 dbar.

and attached and isolated vortices of cold or warm waters at several depth levels [Käse and Siedler, 1982; Käse et al., 1985; Armi and Zenk, 1984]. There is also significant temporal variability at some locations in the Canary Basin. Long-term local current meter moorings reveal strong current events which can be directly associated with the passage of the Azores Current or meddies [Siedler et al., 1985].

To compare our low pass-filtered time series (tidal and higher frequency signals were eliminated) with the hydrographic data from Oceanus and Meteor, we had to perform a second horizontal temperature mapping with a smaller $(<100$ $\mathrm{km})$ search radius and thus less smoothing. A simultaneous analysis of the quasi-synoptic temperature and dynamic height distribution together with current and temperature long-term observation allows us to draw a more detailed picture of water mass advection in the Canary Basin in autumn 1984.

For practical reasons we use $1400 \mathrm{~m}$ as our deep reference level, being well aware of earlier observations [Siedler et al., 1985] that showed a layer of minimum motion at about 3200 $\mathrm{m}$. For the upper integration limit we chose $100 \mathrm{~m}$ to exclude the highly variable near-surface $T / S$ relationship necessary for the calculation of inferred salinity from XBT observations. Because the Azores Current is generally confined to the upper $1000 \mathrm{~m}$ [Käse and Siedler, 1982], the speeds below our reference level are small, and we can expect the 100 - to $1400-\mathrm{m}$ dynamic topography to be a fair representation of the mesoscale current field in the central Canary Basin.

Since water mass differences occur in the observational area, we could not use a unifying historical $T / S$ relationship. Instead, an average of two neighbouring hydrocasts, weighted by its relative distance, was applied. For instance, a nearly perfect correlation between actual dynamic topography values and those with salinity inferred from Emery and Dewar [1982], $T / S$ curve 9 , appeared for the upper $700 \mathrm{~m}$ north of $30^{\circ} \mathrm{N}$. However, for the range below $700 \mathrm{~m}$, a systematic deviation was seen between direct estimates from actual hydrocast of CTD stations and inferred density. The total range of dynamic topography differences due to a constant $T / S$ relationship amounts to \pm 4 dyn $\mathrm{cm}$. In our calculations the error decreased to \pm 1 dyn $\mathrm{cm}$ for an average salinity deviation $<0.025$ PSU in the Mediterranean Water and the Middle Deep Water range.

The most striking feature of the dynamic topography (Figure 8 ) is the general meridional alignment of isolines separating a central low-pressure cell from two co-lateral high- pressure cells. This pattern of the relative topography is associated with the meandering of the Azores Current, first described by Käse et al. [1985] for a different mesoscale case study in the same region in spring 1982. In contrast to this "Poseidon" box survey from 1982, here we find a large displacement of the meandering system to the south in autumn 1984 ; i.e., the pronounced dynamical low, found in the "Poseidon" box at $35^{\circ} \mathrm{N}$, appears to be shifted to a comparable low in 1984 , seen at $32^{\circ} \mathrm{N}$ south of mooring KIEL276 in Figure 8. This substantial shift is not inconsistent with the progressive vector diagram at $560 \mathrm{~m}$ (Figure $7 \mathrm{~b}$ ) that shows a large north to south displacement of approximately $500 \mathrm{~km} / 100$ days in early 1984.

Included in Figure 8 are the locations of four cross sections (A-D) and three current vectors, two derived from actual ship drift observations and one representing the 4-week average velocity at $560 \mathrm{~m}$ in mooring KIEL276. The current directions from the surface and from the thermocline current meter are in good agreement with the dynamic topography contours. The vertical current shear can be seen in Figure 9, where we depict the geostrophical profiles A-D.

Because of their orientation perpendicular to the contours, they represent major components of the actual currents. Geostrophic profiles in Figure 9 agree well with similar distributions obtained in the Azores Current in spring 1981 and 1982 [Käse et al., 1985; Siedler et al., 1985]. Profile D differs from the rest by its small vertical shear in the upper $800 \mathrm{~m}$. To see why this occurs, we present mesoscale temperature maps (Figure 10) and compare them with the temperature at current meter levels 560,1160 , and $1660 \mathrm{~m}$.

At the mooring site, where the geostrophic shear profile D was taken, there are low temperature gradients, apparently caused by local mixing induced from the MW level (Figure $10 b)$, indicating exceptionally warm water $\left(>9.7^{\circ} \mathrm{C}\right)$ just east of mooring KIEL276. This high-temperature tongue is associated with middepth anticyclonic motion that has influenced the shape of the easternmost geostrophic profile D in Figure 9.

In Figure 7 there is a predominant westward advection in the upper water column during fall 1984 which fits well with our temperature maps: at $560 \mathrm{~m}$ the local mooring temperature varies between $11.3^{\circ} \mathrm{C}$ and $11.6^{\circ} \mathrm{C}$ during early October 1984. A more abrupt temperature rise is seen at the $1160-\mathrm{m}$ level, where a change of $O\left(0.8^{\circ} \mathrm{C} \mathrm{d}^{-1}\right)$ is observed immediately before mooring recovery $\left(T=9^{\circ} \mathrm{C}\right)$. We interpret this drastic rise as the passage of the warm water front which is seen, but poorly resolved, in Figure $10 \mathrm{~b}$. We also note that in the lowgradient region southwest of mooring KIEL276 an isolated meddy was detected simultaneously [Käse and Zenk, 1986]. (To avoid unwanted dispersion of its sharp outer limits by automatic contouring, we have here excluded data points from the meddy itself.)

More insight into the structure of the $1660-\mathrm{m}$ temperature time series can be gained by comparing it with the horizontal map at the same level (Figure 10c). There we find (1) a warm tongue in the southeast $\left(>5.6^{\circ} \mathrm{C}\right),(2)$ a transition zone with weak gradients west of mooring KIEL276; $\left(5.2^{\circ} \mathrm{C}\right)$, and (3) cold water $\left(<4.9^{\circ} \mathrm{C}\right)$ in the north. Abrupt changes in the temperature time series appear to be associated with advection of this three-mode structure past the mooring.

\section{Discussion}

The most significant result of this study is that for the first time we have combined a quasi-synoptic mesoscale survey with a large-scale hydrographic survey, which resolved many 
features of the general circulation in the eastern North Atlantic. Direct current measurements were coupled with maps of the hydrographic features, and a consistent picture of the current system was drawn. This region, historically thought to be rather simple and quiescent, was found to be complex and active. We found a convoluted current system dominated by the time-dependent meandering of the Azores Current.

The large-scale dynamic topography, shown in Figure 11 as a smoothed map for the pressure levels 100 referenced to 800 dbar, clearly shows the subtropical anticyclonic gyre similar to that seen in historical maps by Stramma [1984]. The eastward transport relative to $1400 \mathrm{dbar}$ in the range $100-800$ by the Azores Current is $19 \times 10^{6} \mathrm{~m}^{3} \mathrm{~s}^{-1}$ between $28^{\circ} \mathrm{N}$ and $35^{\circ} \mathrm{N}$ along $26^{\circ} 30^{\prime} \mathrm{W}$. However, only $8 \times 10^{6} \mathrm{~m}^{3} \mathrm{~s}^{-1}$ return along the $28^{\circ} \mathrm{N}$ section west of $15^{\circ} \mathrm{W}$. Another $8 \times 10^{6} \mathrm{~m}^{3} \mathrm{~s}^{-1}$ are returned northward between $17^{\circ} \mathrm{W}$ and $10^{\circ} \mathrm{W}$, north of $38^{\circ} \mathrm{N}$. This northward flow was seen in earlier work by Pollard and $P u$ [1985] leading to a confluence area where Subpolar Mode Water and more saline, warm water of the subtropical gyre form a visible frontal zone in infrared satellite pictures. A similar flow pattern was already suggested by Helland-Hansen and Nansen [1926]. The ultimate fate of this northward return flow is not known. Part of it must be returned to the south in the Portugal Current as a narrow eastern boundary current which feeds the Canary Current between the Canaries and the African coast.

The cold water pool in the large scale temperature maps (Figures $5 a, 5 b$, and $5 c$ ), denoted as Subpolar Mode and Labrador Sea Water, are visible signs of a subtropical recirculation of convectively formed water masses [T alley and McCartney, 1982; McCartney and Talley, 1982]. However, this westward recirculation seems to be restricted to the north of the Azores Current. A progression of cold subpolar water directly east of the Azores appears also in the drifter maps of Krauss and Käse [1984] with some drifters entering the Azores Current system, while others break through it and return with the general southwestward circulation south of $29^{\circ} \mathrm{N}$.

Current meter progressive vector diagrams in the central area from fall 1983 to 1984 reveal large zonal and meridional excursions, suggesting meandering motion consistent with the mesoscale analysis of the hydrographic data. The $560-\mathrm{m}$-level exhibits an Azores Current meander with northward displacement between December 1983 and January 1984 and a similar southward return between February and April. The meridional amplitude of this meandering is about $400 \mathrm{~km}$ (Figure 7). During these 5 months a net eastward displacement of the same amount occurred, which would correspond to a mean eastward velocity of about $3 \mathrm{~cm} \mathrm{~s}^{-1}$. However, this eastward tendency is reversed from June to October 1984. This apparent yearly cycle in the east component is not typical for the preceding 5 years of current meter measurements at the same position.

We interpret this behavior as being due to the combined effect of the conjectured detachment of the cold cyclonic meander seen in the vicinity of the mooring (Figure 8) and the subsequent westward advection of this circulation flow pattern past the mooring site.

It should be pointed out that relative geostrophic transport estimates may suffer from large errors because the current meter data have a strong ( $>2 \mathrm{~cm} \mathrm{~s}^{-1}$ ) barotropic signal. Sometimes, for instance, in December 1983 to March 1984, the flow shows a maximum at middepth in the Labrador Sea Water level with speeds as high as $15 \mathrm{~cm} \mathrm{~s}^{-1}$ for 1 month. The temperature maps from our October experiment at this level
(Figure $4 c$ ) showed a remarkable intermediate temperature minimum of approximately $5.25^{\circ} \mathrm{C}$, an indication that cold Labrador Sea Water $\left(T<4.5^{\circ} \mathrm{C}\right)$ had penetrated through the Mediterranean Water tongue $(T>5.6)$ and had been mixed with it, as is suggested by the current meter data.

Given this complicated flow pattern, we were not able to estimate transports in the MW level and below from these data. Clearly, more measurements are needed at this level to resolve the complicated horizontal structure. Long-term temperature measurements in moorings along $28^{\circ} \mathrm{N}$ and $26^{\circ} 30^{\prime} \mathrm{W}$ by the Kiel Institute and acoustically tracked floats from the Woods Hole Oceanographic Institution deployed in fall 1984 and 1985 may help further interpretation of the circulation pattern.

Acknowledgments. We thank T. Müller and L. Armi for providing some of the Meteor CTD data and Oceamus XBT data used in our study. Support for R. H. K. and W. Z was provided by Deutsche Forschungsgemeinschaft (SFB 133), and support for J. F. P. and P. L. R. was provided by the U.S. National Science Foundation through grant OCE82-14066. Thanks go to J. Rathlev for technical assistance in collecting the XBT data and to C. Tietze, C. Wooding, and T. McKee for help preparing the manuscript. Woods Hole Oceanographic Institution contribution 6047.

\section{REFERENCES}

Armi, L., and H. Stommel, Four views of a portion of the North Atlantic subtropical gyre, J. Phys. Oceanogr., 13(5), 828-857, 1983.

Armi, L, and W. Zenk, Large lenses of highly saline Mediterranean Water, J. Phys. Oceanogr., 14, 1560-1576, 1984.

Dietrich, G., Atlas of the Hydrography of the Northern North Atlantic Ocean, 140 pp., Conseil International pour l'Exploration de la Mer, Charlottenlund Slot, Denmark, 1969.

Emery, W. J., and J. S. Dewar, Mean temperature-salinity, salinitydepth and temperature-depth curves from the North Atlantic and the North Pacific, Prog. Oceanogr., 11, 219-305, 1982.

Gould, W. J., Physical oceanography of the Azores Front, Prog. Oceanogr., 14, 167-190, 1985.

Helland-Hansen, B., and F. Nansen, 1926. The eastern North Atlantic, Geophys. Norv., 4, 75 pp., 1926.

Käse, R. H. and G. Siedler, Meandering of the subtropical front southeast of the Azores, Nature, 300(5889), 245-246, 1982.

Käse, R. H. and W. Zenk, Reconstructed Mediterranean salt lens trajectories, J. Phys. Oceanogr., in press, 1986.

Käse, R. H., W. Zenk. T. B. Sanford, and W. Hiller, Currents, fronts and eddy fluxes in the Canary Basin, Prog. Oceanogr., 14, 231-257, 1985.

Krauss, W., The North Atlantic Current, J. Geophys. Res., 91(C4), 5061-5074, 1986.

Krauss, W., and R. H. Käse, Mean circulation and eddy kinetic energy in the eastern North Atlantic, J. Geophys. Res., 89, 3407 3415,1984 .

Levitus, S., Climatological atlas of the world ocean, Prof. Pap. 13, 173 pp., Natl. Oceanic and Atmos. Admin, Rockville, Md., 1982.

Mann, C. R., The termination of the Gulf Stream and beginning of the North Atlantic Current, Deep Sea Res., 14, 337-359, 1967.

McCartney, M. S., and L. D. Talley, The Subpolar Mode Water of the North Atlantic Ocean, J. Phys. Oceanogr., 12, 1169-1188, 1982.

Meincke, J., E. Mittelstaedt, K. Kremling, W. Zenk, and P. Koske, Forschungsschiff 'Meteor', Reise Nr. 69, Nordostatlantik '84, NOAMP III, Ber, der Wiss. Leiter 1-85, 123 pp., Inst. für Meereskunde, Hamburg, Federal Republic of Germany, 1985.

Olbers, D. J., M. Wenzel, and J. Willebrand, The inference of North Atlantic circulation patterns from climatological hydrographic data, Rev. Geophys., 23(4), 313-356, 1985.

Pollard, R. T., and S. Pu, Structure and circulation of the upper Atlantic Ocean northeast of the Azores, Prog. Oceanogr., 14, 443 $462,1985$.

Saunders, D. M., Circulation in the eastern North Atlantic, J. Mar. Res., 40, suppl., 641-657, 1982.

Siedler, G., W. Zenk, and W. J. Emery, Strong current events related to a subtropical front in the Northeast Atlantic, J. Phys. Oceanogr. 15, 885-897, 1985. 
Stramma, L., Geostrophic transport in the warm water sphere of the eastern subtropical North Atlantic, J. Mar. Res., 42, 537-558, 1984.

Talley, L. D., and M. S. McCartney, Distribution and circulation of Labrador Sea Water, J. Phys. Oceanogr., I2, 1189-1205, 1982.

Worthington, L. V., On the North Atlantic circulation, Oceanogr. Stud. 6, 110 pp., Johns Hopkins Univ., Baltimore, Md., 1976.

Wüst, G., 1936. Die Stratosphäre des Atlantischen Ozeans, Wiss. Ergeb. Disch. Atl. Exped. Vermessungs. Forschungsschiff Meteor, 6(1), 109-288, 1936.

Zenk, W., On temperature and salinity structure in the Mediterranean Water in the northeast Atlantic, Deep Sea Res., 17, 627-632, 1970.
R. H. Käse and W. Zenk, Institut für Meereskunde an der Universität Kiel, Düsternbrooker Weg 20, D 2300 Kiel 1, Federal Republic of Germany.

J. P. Price and P. L. Richardson, Woods Hole Oceanographic Institution, Woods Hole, MA 02543.

(Received December 6, 1985; accepted January 7,1986 .) 